\title{
Coexistence Of Ectopic Tubal Pregnancy With A Tuba-Ovarian Abscess in The Same Adnexa: A Case Report
}

\author{
Aynı Adneksde Tuba-Ovaryan Abse ile Ektopik Tubal Gebeliğin Bir Arada Bulunması: Bir Olgu \\ Sunumu
}

Melike Geyik Bayman, Zeynep Ozturk Inal, Hasan Ali Inal

Konya Training and Research Hospital, Departmant of Obstetrics and Gynecology, Konya, Turkey

\section{ABSTRACT}

Ectopic pregnancy (EP), seen in approximately $1.3-2 \%$ of all pregnancies, is defined as the placement of the fertilized ovum outside of the uterine cavity and it is the most important cause of maternal morbidity and mortality in the first trimester. Tuba ovarian abscess (TOA) is a polymicrobial infection that can involve the ovary, fallopian tubes, and adherent organs, which is usually seen in $15 \%$ of women with pelvic inflammatory disease in the reproductive period. Here, we aimed to present a patient with three previous miscarriages in the last year, who was admitted to the emergency department with symptoms of recurrent abdominal pain and vaginal bleeding, and who was diagnosed as having ectopic pregnancy and tubal ovarian abscess in examinations and tests. She recovered well after laparoscopic surgery. Diagnosis of both EP and TOA as early as possible and timely medical intervention are important in reducing maternal morbidity and mortality.

Key words: Ectopic pregnancy, laparoscopy, tuba ovarian abscess.

\section{INTRODUCTION}

Ectopic pregnancy (EP) caused by the placement of the fertilized ovum outside the uterine cavity is seen in 1.3 and $2.4 \%$ of pregnancies in the reproductive period. EP is the most important cause of maternal morbidity and mortality $(6-13 \%)$ of first trimester $(1,2)$. Ninety-five percent of EP can be seen in the tubular uterine and the ampulla, isthmus, and interstium, respectively, as well as in the ovary, cervix, and intraabdominal region (3). Previous pelvic/tubal surgery, history of pelvic inflammatory disease, history of infertility, and inutero diethylstilbestrol (DES) exposure are among the most important risk factors; smoking and sexually transmitted

\section{ÖZET}

Tüm gebeliklerin yaklaşık \% 1.3-2'sinde görülen ektopik gebelik $(E G)$, fertilize yumurtanın uterin kavite dışına yerleşmesi olarak tanımlanır ve ilk trimesterdeki maternal morbidite ve mortalitenin en önemli nedenidir. Tubo-ovaryan abse (TOA), üreme döneminde pelvik inflamatuar hastalığı olan kadınların \% 15 'inde görülen yumurtalık, fallop tüpleri ve komşu organları tutabilen bir polimikrobiyal enfeksiyondur. Burada son bir yıl içinde daha önce üç düşük yapmış, tekrarlayan karın ağrısı ve vajinal kanama semptomları ile acil servise başvuran, muayene ve tetkiklerde ektopik gebelik ve tubo-ovaryan abse tanısı konulan bir hastayı sunmayı amaçladık. Olgu laparoskopik cerrahi sonrası iyileşmiştir. Hem EG hem de TOA'nın mümkün olduğu kadar kısa sürede teşhisi ve zamanında uygun tıbbi müdahale maternal morbidite ve mortaliteyi azaltmada önemlidir.

Anahtar Kelimeler: Ektopik gebelik, laparoskopi, tubo-ovaryan abse

diseases increase the risk of EP (4). Delayed menstruation, light vaginal bleeding, and pelvic pain are the classic symptoms of unruptured EP, and acute abdominal symptoms can be seen together with rupture (3).

Despite the dizzying development of ultrasonographic imaging with technology, the diagnosis of EP and therefore its treatment may still be delayed and may be life-threatening (2). Tuba-ovarian abscess (TOA) is a complication of PID, which is a polymicrobial infection accompanied by aerobic and anaerobic bacteria that occurmore frequently in the reproductive period (5). Recently, with the increase of sexually transmitted

Corresponding author: Hasan Ali Inal, Konya Training and Research Hospital, Departmant of Obstetrics and Gynecology, Konya, Turkey E-mail: dr.hasanaliinal@yahoo.com

Eskisehir Med. J. 2021; 2(2):124-7.

Received Date:16.04.2021 Accepted date:21.06.2021

Authors: Melike Geyik Bayman (ORCID: 0000-0003-0008-2205), Zeynep Ozturk Inal (ORCID: 0000-0002-8766-2079), Hasan Ali Inal (ORCID: 00000002-8361-7908) 
diseases, the frequency of TOA due to PID has also increased. Although Neisseria gonorrhea and Chlamydia trachomatis are often thought to be factors in the pathogenesis of TOA, Escherichia coli and Bacteroides species have also been isolated $(5,6)$. The treatment of TOA, which can cause infertility, EP, chronic pelvic pain, ovarian vein thrombosis, and pelvic thrombophlebitis, is primarily medical, and $75 \%$ of patients respond to this treatment. Patients who do not respond require surgical intervention. Rupture, peritonitis, and sepsis complications occur in patients whose treatment is delayed or absent, and this may result in death (5).

Because of the diagnosis of EP as early as possible and timely medical intervention are important in reducing maternal morbidity and mortality, we aimed to present a patient who was diagnosed as having EP and tubal ovarian abscess and recovered after laparoscopic surgery.

\section{CASE REPORT}

A 37-year-old patient, who presented to the emergency department of our hospital with symptoms of abdominal pain and light vaginal bleeding for the last 3 days, had three normal births and a history of three miscarriage and curettages. Pain, rebound, and defense were positive in the right lower quadrant of the abdomen. Her blood pressure was $80 / 50 \mathrm{mmHg}$, pulse 120 beats/min, respiratory rate $24 / \mathrm{min}$, and she had fever $38.7^{\circ} \mathrm{C}$. A laboratory evaluation revealed the following:hemoglobin $(\mathrm{Hb}): 9.8 \mathrm{~g} / \mathrm{dL}$, hematocrit: $28.5 \%$, white blood cell: $16.82\left(\times 10^{3}\right)(\mathrm{mcL})$, platelet count: $443\left(\times 10^{3}\right)(\mathrm{mcL}), \mathrm{C}$ reactive protein (CRP): $189(\mathrm{mg} / \mathrm{dL})$, beta-human chorionic gonadotropin (hCG): 2743 (mIU/L).

In the transvaginal ultrasonography evaluation, in the right adnexal region of pelvic area, a regular gestational sac (Fig 1A) containing a yolc-sac was seen, which was thought to be an ectopic pregnancy focus. A mass (Fig 1B) with a diameter of about $10.4 \times 9.510 .2 \mathrm{~cm}$ in the
Douglas pouch, which was thought to be compatible with a heterogeneous abscess was observed. In our case, an emergency surgery decision was made due to the findings of acute abdomen and EP. Detailed information was given to the patient and her husband and it was decided to perform emergency laparoscopy. Informed consent was obtained from the patient.

On exploration, the uterus fundus superior was highly connected with the anterior abdominal wall and peritoneum, the left ovary and left tuba were natural in appearance.In the right adnexal area, there was a finding compatible with an abscess (the largest diameter $10 \mathrm{~cm}$ ), which was highly connected to the rectum and uterus posterior. In the right tuba-bulbs region, an extremely tight, unruptured ectopic pregnancy focus of approximately $3 \times 2 \mathrm{~cm}$ was observed. After separating all the connections using blunt and sharp dissection, the abscess contents were drained and right salpingectomy was performed because the patient had a desire for sterilization.We performed left tuba ligation. The inside of the abdomen was washed with approximately $2000 \mathrm{cc}$ of isotonic saline. After confirming hemostasis, a drain was placed in the Douglas pouch. Postoperative parenteral dual antibiotic treatment (clindamycin and gentamicin) was initiated, the patient's fever decreased, laboratory findings compatible with inflammation improved, and the patient was discharged as cured. Written informed consent was obtained for the presentation of the case and the publication of accompanying images.

\section{DISCUSSION}

$E P$, which is the most important cause of maternal morbidity and mortality in the first trimester of pregnancy, has increased in recent years with the increase of sexually transmitted diseases and more widespread use of assisted reproductive techniques $(3,6)$. It is very important to diagnose ectopic pregnancy 


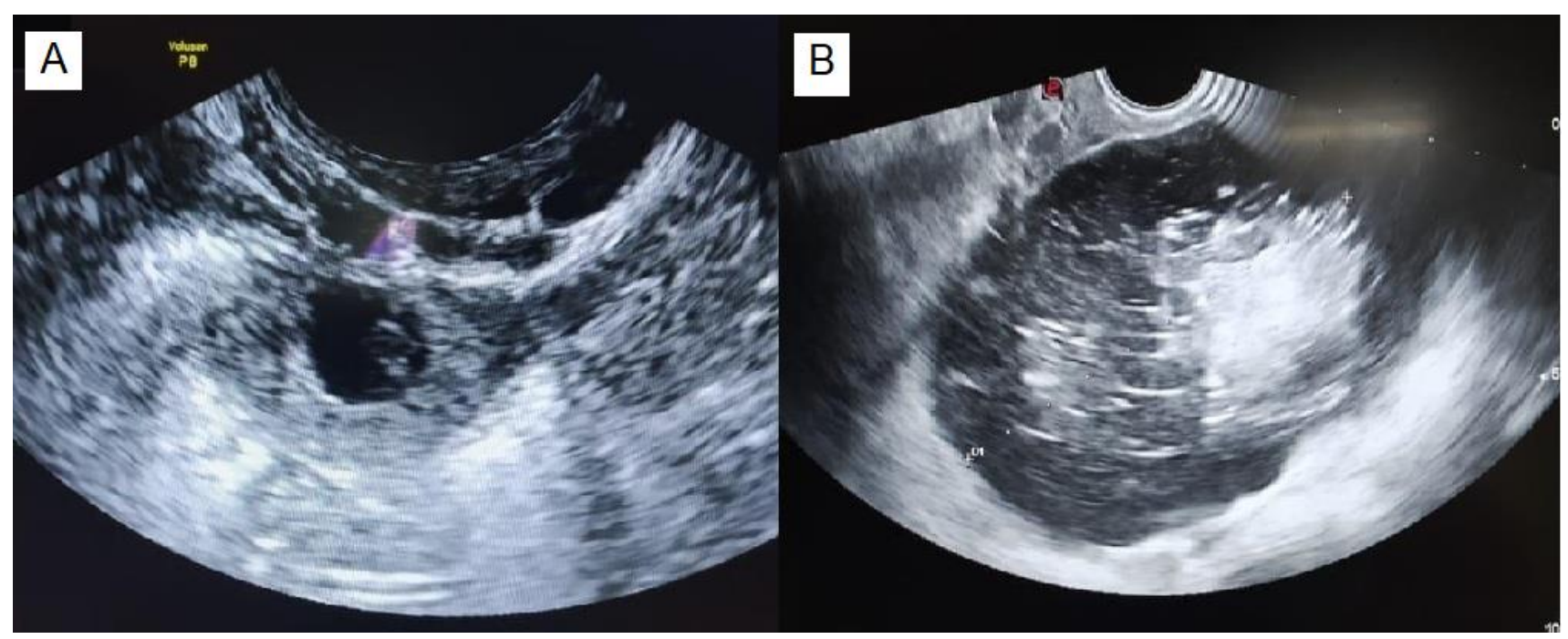

Figures 1A and B: Transvaginal ultrasonographic view of ectopic pregnancy and tubo-ovarian abscess.

without delay because the time to diagnosis is directly related to the patient's morbidity and mortality (6). With the use of USG devices, whose image quality has increased with advances in technology, in daily routine practice, EP has become easier to diagnose, and as a result, although the incidence of EP has increased, mortality rates have tended to decrease $(2,3)$. One of the most important predisposing factors of ectopic pregnancy is pelvic inflammation, and it is thought that ectopic pregnancy occurred as a result of a pelvic abscess in our case, and therefore, tube mobility is reduced due to inflammation affecting the right ovary and tuba.

TOA is usually seen in the reproductive period, which causes pain in the lower abdominal quadrants and pelvic region, and mostly polymicrobial agents are responsible for the etiopathogenesis $(5,6)$. TOA is usually seen as inflammatory masses involving the fallopian tubes and is highly associated with the ovaries and other pelvic organs $(7,8)$. Early diagnosis and treatment are very important in TOA because it can cause infertility and more importantly, if ruptured, it can be fatal (9).

Laparoscopy is accepted as the gold standard in the diagnosis and treatment of ruptured ectopic pregnancy and TOA $(3,10)$. In our case, no complications were observed with the laparoscopic minimally invasive surgical method. The decision for salpingectomy or salpingostomy in tubal EP surgery depends on the age of the patient and the desire for fertility and the damage in the tube where the EP is loctated. In our case, the tubule was highly hydropic, bloody pus was discharged from the tuba. The patient did not desire fertility so this reason salpingectomy and ligation was performed to the left tuba.

In conclusion, early diagnosis of both ectopic pregnancy and tubal ovarian abscess and making the necessary medical treatment and intervention as soon as possible is vital in reducing maternal morbidity and mortality.

Informed Consent: Informed consent was taken from the patient.

Conflict of Interest: The authors declare that there is no conflict of interest.

Funding: No funding was taken for this study.

\section{REFERENCES}

1. Walker JJ. Ectopic pregnancy. Clin Obstet Gynecol. 2007 Mar;50(1):89-99. 
2. Taran FA, Kagan KO, Hübner M, Hoopmann M, Wallwiener D, Brucker S. The Diagnosis and Treatment of Ectopic Pregnancy. Dtsch Arztebl Int. 2015 Oct 9;112(41):693-703; quiz 704-5.

3. Inal ZO, Inal HA. Comparison of Four Methods of Treating Ectopic Pregnancy: A Retrospective Cohort Study. Geburtshilfe Frauenheilkd. 2018 Jan;78(1):70-77.

4. Murray $\mathrm{H}$, Baakdah $\mathrm{H}$, Bardell $\mathrm{T}$, Tulandi T. Diagnosis and treatment of ectopic pregnancy. CMAJ. 2005 Oct 11;173(8):90512.

5. Inal ZO, Inal HA, Gorkem U. Experience of Tubo-Ovarian Abscess: A Retrospective Clinical Analysis of 318 Patients in a Single Tertiary Center in Middle Turkey. Surg Infect (Larchmt). 2018 Jan;19(1):54-60.

6. Inal HA, Ozturk Inal Z, Alkan E. Successful Conservative Management of a Dislocated IUD. Case Rep Obstet Gynecol. 2015;2015:130528.

7. Kinay $T$, Unlubilgin E, Cirik DA, et al. The value of ultrasonographic tubo-ovarian abscess morphology in predicting whether patients will require surgical treatment. Int $\mathrm{J}$ Gynaecol Obstet. 2016;135(1):77-81.

8. Inal ZO, Inal HA. Bilateral Dermoid Cysts of the Ovaries in a Term Pregnant Woman: A Case Report. Anatol JFM 2018;1(2):67-69.

9. Akkurt MÖ, Yalçın SE, Akkurt $\mathrm{i}$, et al. The evaluation of risk factors for failed response to conservative treatment in tuboovarian abscesses. J Turk Ger Gynecol Assoc. 2015;16(4):22630.

10. Inal ZO, Inal HA. Comparison of abdominal, vaginal, and laparoscopic hysterectomies in a tertiary care hospital in Turkey. Ir J Med Sci. 2018;187(2):485-91. 